\title{
PERBANDINGAN HASIL BELAJAR BIOLOGI DENGAN MENGGUNAKAN MODEL PEMBELAJARAN KOOPERATIF SCRIPT DAN MODEL PEMBELAJARAN KONVENSIONAL PADA POKOK BAHASAN SISTEM ESKRESI DI KELAS VIII SMP MUHAMMADIYAH 11 TELLO MAKASSAR
}

\section{Comparation of Biology Learning Result Using Script Cooperative Learning and Conventional Learning Model on Chapter Excretion System in VIII ${ }^{\text {th }}$ Grade Students of SMP Muhammadiyah 11 Tello Makassar}

\author{
Muh. Rizaldi Trias Jaya Putra N \\ STKIP Pembangunan Indonesia, Makassar, Indonesia \\ email: rizaldi.bsh@gmail.com
}

\begin{abstract}
In the world of education, improving the quality of learning both in the mastery of materials and learning methods are always strived. One of the efforts that teachers do in improving the quality of teachers is the preparation of various scenarios of learning activities in the classroom. This study aims to determine the comparison of biological learning outcomes by using cooperative learning model script and conventional learning model. This research was conducted at SMP Muhammadiyah 11 Tello Makassar in March until April 2016. The research method used was a Quasy Eksperiment. The research instrument used is the learning result instrument and tested through t-test statistic. The results obtained that $\mathrm{t}$-count value for post-test data in the experimental class of 3.81 while t-table at the level of significance level $\alpha 5 \%$, then the value of $\alpha$ designated in table $t$ is 2.00 , so obtained $t$ count $\geq t$ table $(3.81 \geq 2.00)$. This study suggested that cooperative learning scripts can improve students learning outcomes.
\end{abstract}

Keywords: Cooperative Learning script, Conventional Learning, Learning outcomes 


\section{PENDAHULUAN}

Proses pembelajaran merupakan bagian dari sistem pendidikan. Harold Spear dalam Martinis Yamin (2004), mendefinisikan bahwa belajar terdiri dari pengamatan, pendengaran, membaca dan meniru. Belajar menghasilkan perubahan dalam diri individu sebagai akibat interaksi individu dengan individu lainnya atau dengan lingkungannya. Mengajar merupakan kegiatan yang dilakukan oleh guru untuk membimbing siswa dalam kegiatan belajar dalam hal ini guru berperan untuk mengorganisasikan lingkungan yang berhubungan dengan anak didik dan bahan pembelajaran dalam rangka pencapaian tujuan belajar.

Belajar mengajar suatu kegiatan yang edukatif. Nilai eduktif mewarnai interaksi yang terjadi antara guru dengan siswa. Interaksi tersebut terjadi karena kegiatan belajar mengajar diarahkan untuk mencapai sebuah tujuan tertentu yang telah dirumuskan sebelum pelajaran dilakukan. Salah satu masalah pokok dalam pembelajaran di sekolah adalah masih rendahnya daya serap siswa. Hal ini nampak rata-rata hasil bejajar siswa yang senantiasa masih sangat memprihatinkan. Prestasi ini merupakan hasil kondisi pembelajaran yang masih bersifat konvensional dan tidak menyentuh ranah dimensi siswa itu sendiri (belajar untuk belajar).

Pada proses pembelajaran biologi berlangsung di sekolah masih banyak didominasi oleh guru, dimana guru sebagai sumber utama pengetahuan. Dalam proses pembelajaran ini metode ceramah menjadi pilihan utama strategi pembelajaran. Pola pembelajaran yang dilakukan, diawali penjelasan singkat materi oleh guru di lanjutkan dengan pemberian contoh soal, dan diakhiri dengan latihan soal. Pola ini dilakukan secara menonton dari waktu ke waktu. Dalam pembelajaran ini, konsep yang di terima siswa berasal dari Guru (Zurinal, 2006). Pada pembelajaran ini suasana kelas cenderung teacher centered sehingga siswa menjadi pasif, sehingga perlu dilakukan upaya pembelajaran yang melibatkan interaksi guru dan siswa. Salah satunya adalah pembelajaran kooperatif. 
Pembelajaran kooperatif (cooperative learning) merupakan pendekatan dalam proses belajar-mengajar yang berbasis kelompok. Model pembelajaran ini sangat berguna untuk membantu siswa menumbuhkan kemampuan kerjasama, berfikir kritis dan kemampuan membantu teman. Pembelajaran ini akan menciptakan siswa untuk berpartisispasi aktif ikut serta secara aktif dan ikut serta bekerja sama hingga antar siswa akan berfikir bersama, melakukan penyelidikan bersama dan berbuat ke arah yang sama. Pembelajaran kooperatif dapat merangsang siswa supaya lebih bersemangat dalam belajar, jika sistem belajar dalam pembelajaran disajikan dengan menarik dan terarah dalam mengkaji sesuatu permasalahan atau materi yang akan di sampaikan (Anita, 2003).

Menurut Sereau dalam Slavin (2007), model pembelajaran Cooperative Script yaitu skenario dalam pembelajaran kooperatif. Artinya setiap siswa mempunyai peran saat malakukan diskusi, Pembelajaran Cooperative Script juga merupakan pembelajaran yang menggambarkan interaksi siswa sepertiilustrasi kehidupan sosial siswa dengan lingkungannya sebagai individu, dalam keluarga, kelompok masyarakat, dan masyarakat yang lebih luas. Sedangkan Menurut Slameto (2003), bahwa model pembelajaran cooperative script adalah secara tidak langsung terdapat kontrak belajar antara guru dengan siswa dan siswa dengan siswa mengenai cara berkolaborasi.

Hasil belajar mencerminkan sejauh mana siswa telah mencapai tujuan yang telah ditetapkan di setiap studi. Hasil belajar merupakan hasil dari suatu usaha, kemampuan dan sikap seseorang dalam menyelesaikan suatu hal dibidang pendidikan. Menurut Bagne dan Briggs dalam Heriyanto (2006), ada lima kategori kapabilitas hasil belajar yaitu: (1) keterampilan intelektual, (2) strategi kognitif, (3) informasi verbal, (4) keterampilan motorik, (5) sikap. Sedangkan berdasarkan Bloom dan kawankawan mengklasifikasikan hasil belajar menjadi tiga ranah atau domain yaitu ranah kognitif, ranah efektif, ranah psikomotorik. Ranah kognitif menaruh perhatian pada pengembangan kapabilitas dan keterampilan intelektual, ranah psikomotorik berkaitan dengan kegiatan-kegiatan atau keterampilan dan ranah 
efektif berkaitan dengan pengembangan perasaan, sikap, nilai dan emosi (Arikunto \& Suharsini, 2007).

Berdasarkan deskripsi teoritis tersebut maka hipotesis penelitian ini yaitu terdapat perbedaan hasil belajar biologi antara siswa yang belajar melalui pembelajaran kooperatif script dengan pembelajaran konvensional pada pokok bahasan sistem ekskresi di kelas VIII SMP Muhammadiyah 11 Tello Makassar.

\section{METODE PENELITIAN}

Metode yang digunakan dalam penelitian ini adalah metode eksperimen. dalam metode eksperimen, desain eksperimen ini terdapat kelompok eksperimen dan kelompok kontrol, dimana kelompok eksperimen adalah kelompok yang diberikan perlakuan khusus yaitu kooperatif tipe script, sedangkan kelompok kontrol adalah pembelajaran konvensional. Desain penelitian yang digunakan pada penelitian ini yaitu menggunakan Non Randomized kontrol group pretest-postest Design.

\section{Teknik Pengambilan Sampel}

Populasi dalam penelitian ini adalah kelas VIII SMP Muhammadiyah 11 Tello Makassar. Sampel penelitian adalah sebagian dari populasi yang akan diteliti. Sedangkan sampel pada penelitian ini kelas VIII dengan jumlah siswa 30 orang menggunakan tekhnik Purposive sampling.

\section{Teknik Pengumpulan Data}

1. Tes kognitif

Tes kognitif ini berupa tes tertulis yang diberikan kepada siswa yang berbentuk soal objektif dengan lima pilihan. Soal pretest dan posttest yang bertujuan untuk mengetahui peningkatan hasil belajar biologi khususnya untuk kelas eksperimen.

2. Observasi

Observasi bertujuan mengetahui semua kegiatan siswa dalam proses pembelajaran. 


\section{Teknik Analisis Data}

1. Uji Validitas

Adapun kriteria penilaian validitas Menurut Sugiyono (2003), sebagai berikut:

\section{Tabel 1.}

Kriteria tingkat validitas sebagai berikut:

\begin{tabular}{|c|c|c|}
\hline A & Antara $0,80-1,00$ & Sangat tinggi \\
\hline B & Antara $0.60-0,80$ & Tinggi \\
\hline C & Antara $0,40-0,60$ & Cukup \\
\hline D & Antara $0,20-0,40$ & Rendah \\
\hline E & Antara $0,00-0,20$ & Sangat rendah \\
\hline
\end{tabular}

2. Reliabilitas

Suatu tes yang reliabilitas ditandai dengan adanya koefisien reliabilitas dan rendahnya standard error of measurement. Adapun criteria penilaian reliabilitas menurut Sugiyono (2003), sebagai berikut:

\section{Tabel 2.}

Kriteria tingkat reliabilitas adalah:

\begin{tabular}{|c|c|c|}
\hline A & Antara $0,80-1,00$ & Sangat tinggi \\
\hline B & Antara $0.60-0,80$ & Tinggi \\
\hline C & Antara $0,40-0,60$ & Cukup \\
\hline D & Antara $0,20-0,40$ & Rendah \\
\hline E & Antara $0,00-0,20$ & Sangat rendah \\
\hline
\end{tabular}

\section{Teknik Analisis Data}

Sebelum menentukan teknik analisis data yang akan digunakan, terlebih dahulu memeriksa keabsahan sampel yaitu dengan menguji normalitas dan uji homogenitas, selanjutnya dilakukan uji hipotesis. Teknik analisis data yang digunakan dalam penelitian ini adalah independent sampel t-test. Independent sample t-test adalah jenis uji statistika yang bertujuan untuk membandingkan rata-rata dua grup yang tidak saling berpasangan atau tidak saling berkaitan. Dalam penelitian 
ini uji T-test independent untuk melihat perbedaan antara kelompok kontrol dengan kelompok perlakuan (Sugiono, 2005).

\section{HASIL DAN PEMBAHASAN}

\section{Hasil Belajar Kooperatif Script}

\section{a. Analisis Data Kualitatif}

Data aktifitas siswa diperoleh melalui hasil pengamatan aktifitas dan sikap siswa selama proses pembelajaran disetiap pertemuan. Adapun deskripsi aktifitas siswa sebagaimana dilihat pada Tabel 3. Berikut:

\section{Tabel 3.}

Distribusi Frekuensi Aktifitas dan Sikap Siswa

\begin{tabular}{|l|c|c|c|c|}
\hline \multirow{2}{*}{ Kriteria Penilaian } & \multicolumn{2}{|c|}{ Pertemuan I } & \multicolumn{2}{c|}{ Pertemuan II } \\
\cline { 2 - 5 } & $\boldsymbol{f}$ & $\mathbf{\%}$ & $\boldsymbol{F}$ & $\mathbf{\%}$ \\
\hline $\begin{array}{l}\text { 1. } \\
\text { Siswa memperhatikan } \\
\text { penjelasan guru. }\end{array}$ & 29 & 96 & 30 & 100 \\
\hline $\begin{array}{l}\text { 2. } \\
\text { Siswa tidak mengalami } \\
\text { kesulitan dalam } \\
\text { mengerjakan soal yang } \\
\text { diberikan. }\end{array}$ & 25 & 83 & 28 & 93 \\
\hline 3. $\begin{array}{l}\text { Siswa menyelesaikan } \\
\text { soal sesuai waktu yang } \\
\text { ditentukan }\end{array}$ & 23 & 76 & 25 & 83 \\
\hline $\begin{array}{l}\text { 4. } \\
\text { Siswa menanggapi } \\
\text { jawaban dari } \\
\text { temannya. }\end{array}$ & 8 & 26 & 12 & 40 \\
\hline 5. $\begin{array}{l}\text { Siswa menyimpulkan } \\
\text { materi pelajaran. }\end{array}$ & 12 & 40 & 15 & 50 \\
\hline
\end{tabular}

Berdasarkan Tabel 3. diatas, diperoleh data yaitu dari 2 pertemuan pada pembelajaran kooperatif script, untuk kriteria siswa yang memperhatikan penjelasan guru pada pertemuan pertama sebanyak 29 orang atau 96\% dan pertemuan kedua sebanyak 30 orang atau 100\%. Untuk kriteria siswa yang tidak mengalami kesulitan dalam mengerjakan soal yang diberikan, 
pada pertemuan pertama sebanyak 25 orang atau $83 \%$, dan pertemuan kedua sebanyak 28 orang atau 93\%. Untuk kriteria siswa yang menyelesaikan soal sesuai waktu yang ditentukan, pada pertemuan pertama sebanyak 23 orang atau $76 \%$, dan pertemuan kedua sebanyak 25 orang atau 83\%. Untuk kriteria siswa yang menanggapi jawaban dari temannya, pada pertemuan sebanyak 8 atau 26\%, dan pertemuan kedua sebanyak 12 orang atau 40\%. Untuk kriteria yang terakhir yaitu siswa yang menyimpulkan, pada pertemuan pertama sebanyak 12 orang atau $40 \%$, dan pertemuan kedua sebanyak 15 orang atau $50 \%$.

Berdasarkan data aktivitas siswa di atas tampak adanya peningkatan untuk semua kriteria penilaian dari pertemuan pertama dan kedua. Berikut analisis kuantitatif dari data tersebut:

\section{b. Analisis Data Kuantitatif}

Hasil belajar ini merupakan data awal penelitian dengan menerapkan model pembelajaran kooperatif script. Secara umum data atau hasil yang diperoleh dari kelas VIII SMP Muhammadiyah 11 Tello Baru Makassar setelah menerapkan model kooperatif script pada mata pelajaran Biologi dan sekaligus hasil evaluasi, dari 30 jumlah siswa tersebut hanya 4 orang atau 26,7\% mendapat nilai 90-94, nilai 85-89 hanya dicapai 7 orang atau 23,3 $\%$, nilai 80-84 hanya dicapai 7 orang atau $23,3 \%$, nilai $75-79$ hanya dicapai 4 orang atau 13,3\%, nilai 70-74 hanya dicapai 8 orang atau 26,7 \%. Berdasarkan analisis terhadap nilai hasil belajar setelah menerapkan model pembelajaran kooperatif script meningkatkan hasil belajar Biologi pada siswa kelas VIII SMP Muhammadiyah 11 Tello Makassar.

\section{Deskripsi Data Pembelajaran Konvensional}

\section{a) Analisis Data Kualitatif}

Data aktifitas siswa diperoleh melalui hasil pengamatan aktifitas dan sikap siswa selama proses pembelajaran di setiap pertemuan. Berdasarkan Tabel 5, diperoleh data yaitu dari 2 pertemuan pada pembelajaran konvensional. 
Tabel 4.

Distribusi Frekuensi Aktifitas dan Sikap Siswa

\begin{tabular}{|l|c|c|c|c|}
\hline \multirow{2}{*}{ Kriteria Penilaian } & \multicolumn{2}{|c|}{ Pertemuan I } & \multicolumn{2}{c|}{ Pertemuan II } \\
\cline { 2 - 5 } & $\boldsymbol{F}$ & $\mathbf{\%}$ & $\boldsymbol{F}$ & $\mathbf{\%}$ \\
\hline $\begin{array}{l}\text { 1. Siswa } \\
\text { memperhatikan } \\
\text { penjelasan guru. }\end{array}$ & 28 & 93 & 29 & 96 \\
\hline $\begin{array}{l}\text { 2. Siswa tidak } \\
\text { mengalami kesulitan } \\
\text { dalam mengerjakan } \\
\text { soal yang diberikan. }\end{array}$ & 23 & 76 & 25 & 83 \\
\hline $\begin{array}{l}\text { 3. Siswa menyelesaikan } \\
\text { soal sesuai waktu } \\
\text { yang ditentukan }\end{array}$ & 20 & 66 & 22 & 73 \\
\hline $\begin{array}{l}\text { 4. Siswa menanggapi } \\
\text { jawaban dari } \\
\text { temannya. }\end{array}$ & 5 & 16 & 7 & 33 \\
\hline $\begin{array}{l}\text { 5. Siswa menyimpulkan } \\
\text { materi pelajaran. }\end{array}$ & 7 & 23 & 10 & 33 \\
\hline
\end{tabular}

\section{b) Analisis Data Kuantitatif}

Hasil belajar ini merupakan data awal penelitian dengan menerapkan model pembelajaran konvensional. Secara umum data atau hasil yang diperoleh dari kelas VIII SMP Muhammadiyah 11 Tello Makassar setelah menerapkan model pembelajaran konvensional pada mata pelajaran Biologi dan sekaligus hasil evaluasi, dari 30 jumlah siswa tersebut hanya 7 orang atau 23,3 \% mendapat nilai 80-84, nilai 75-79 hanya dicapai 8 orang atau $26,8 \%$, nilai $70-74$ hanya dicapai 7 orang atau $23,3 \%$, nilai $65-69$ hanya dicapai 4 orang atau 13,3 $\%$, nilai 60-64 hanya dicapai 4 orang atau 13,3\%.

Berdasarkan uraian diatas dapat disimpulkan bahwa dari model pembelajaran kooperatif script dan pembelajaran konvensional diatas menunjukkan bahwa pada pembelajaran kooperatif script dapat mencapai peningkatan hasil belajar siswa sebesar $100 \%$ dari 30 siswa dibandingkan dengan 
pembelajaran konvensional hanya mencapai hasil belajar siswa sebesar $96 \%$ dari 30 siswa.

\section{c) Analisis Statistik}

Berdasarkan analisis data yang diperoleh dapat diketahui bahwa terdapat perubahan hasil belajar siswa antara kooperatif script dengan pembelajaran konvensional baik pada kelas kontrol maupun kelas eksperimen, diketahui bahwa nilai ratarata kemampuan awal siswa yang diperoleh dari hasil pretest untuk kelas kontrol dan kelas eksperimen relative sama, populasi berdistribusi normal, dan homogen. Demikian juga hasil pengujian perbedaan dua rata-rata dengan nilai pretest kelas kontrol dan kelas eksperimen yang menunjukkan tidak adanya perbedaan. Hal ini membuktikan bahwa kedua kelompok tersebut memiliki kemampuan yang relatif sama karena kelompok tersebut tidak dikelompokkan secara khusus. Dari hasil data diperoleh temuan yaitu bahwa diperoleh rata-rata posttest nilai kelompok eksperimen lebih tinggi dibandingkan dengan kelompok kontrol yaitu 73.16 untuk rata-rata kelas kontrol dan 80.6 untuk rata-rata kelas eksperimen.

Hasil analisis statistik diperoleh thitung sebesar 3.81 pada taraf kepercayaan 95\% ( $\alpha=0.05$ atau 5\% ) dan derajat kebebasan 58 sehingga diperoleh nilai $t_{\text {tabel }}$ sebesar 2.00. Hal ini berarti $t_{\text {hitung }} \geq$ table $_{\text {tan }}$ sehingga $\mathrm{H}_{0}$ ditolak. Dengan demikian dapat disimpulkan bahwa hasil belajar siswa mengalami peningkatan melalui model pembelajaran kooperatif script.

Hasil penelitian yang dilakukan oleh Fardila dkk. (2013), diketahui hasil akhir penilaian motivasi siswa pada kelas eksperimen diperoleh sebesar 77,77\% dengan kategori siswa termotivasi dengan mengunakan strategi cooperative script dengan media gambar, sedangkan pada kelas kontrol diperoleh sebesar 70,09\% dengan kategori termotivasi siswa termotivasi dengan pembelajaran konvensional. Data hasil belajar dalam penelitian ini diambil dengan memberikan tes awal dan tes akhir kepada siswa kelas sampel. Sedangkan hasil penelitian serupa yang dilakukan Oktaviyani (2013), Keefektifan metode Cooperative Script pada kelompok eksperimen dapat diketahui 
dengan uji-t yang menunjukkan bahwa data tersebut signifikan. Nilai sebesar 4,555 dengan $d b=76$, nilai p sebesar 0,000 . Nilai $p$ lebih kecil dari pada taraf signifikansi $0,05(0,000<0,05)$ artinya signifikan.

Dari hasil penelitian ini selama proses pembelajaran diketahui bahwa antusias siswa selama proses pembelajaran dengan menggunakan model pembelajaran kooperatif script semakin meningkat di setiap tatap muka. Melalui proses interaksi antar siswa dapat melatih siswa memperoleh pengetahuan serta dapat meningkatkan partisipasi, motivasi, kemampuan berkomunikasi, kemampuan berfikir kritis dan saling menghargai. Kondisi seperti inilah yang membuat siswa merasa tidak bosan dan jenuh dalam proses pembelajaran, sehingga terjadi peningkatan hasil belajar sekitar $76.7 \%$ siswa pada kelas eksperimen menyatakan pembelajaran dengan menggunakan model pembelajaran kooperatif script dirasakan dapat meningkatkan hasil belajar siswa.

\section{KESIMPULAN}

Model pembelajaran kooperatif script dapat meningkatkan kemampuan siswa yang ditunjukkan dengan Persentase hasil belajar siswa sebanyak 76.7\%. Nilai rata-rata posttest kelompok eksperimen lebih tinggi yaitu 80,6 dibandingkan dengan kelompok kontrol yaitu 73.16. Model pembelajaran kooperatif script dapat dijadikan sebagai model belajar alternatif bagi siswa.

\section{DAFTAR PUSTAKA}

Arikunto dan Suharsimi.( 2007). Dasar-dasar evaluasi pendidikan. Jakarta: PT Bumi Aksara.

Anita L. (2003). Cooperatif learning and script, mempraktekkan model pembelajaran di ruang kelas. Jakarta: Gramedia.

Faradila E, samsuri T, Nurhidayati S. (2013). Pengaruh Strategi Cooperative Script Dengan Media Gambar Terhadap 
Motivasi Dan Hasil Belajar Biologi Siswa Kelas Vii Mts AlRaisiyah Sekarbela. Mataram: IKIP Mataram.

Heriyanto. (2006). Jurnal pengajaran MIPA . Jakarta: Balai Pustaka.

Oktaviyani V. (2013). Keefektifan Metode Pembelajaran Cooperative Script Dalam Pembelajaran Membaca Pemahaman Siswa Kelas Vii Smp Negeri 1 Manisrenggo. Skripsi. Pendidikan Bahasa dan Sastra Indonesia. Yogyakarta: Universitas Negeri Yogyakarta.

Slameto. (2003). Belajar dan faktor-faktor yang mempengaruhinya. Jakarta: PT Rineka Cipta.

Slavin Robert E. (2008). Cooperative learning, teori, riset dan praktik. Bandung: Nusa Media.

Sugiyono. (2003). Statistik Penelitian. Bandung : Alfabeta

Trianto. (2007). Model-model pembelajaran inovatif berorientasi kontruktivisme. Jakarta : Presatasi Pustaka.

Yamin, Martinis. (2004). Strategi pembelajaran berbasis kompetensi. Ciputat: Gaung Persada Press.

Zurinal, Z. (2006). Ilmu pendidikan pengantar dan dasar-dasar pelaksanaan pendidikan. Jakarta : UIN Jakarta Press. 